\title{
Prerequisite Coursework As A Predictor Of Performance In A Graduate Management Course
}

Amy McMillan-Capehart, East Carolina University Tope Adeyemi-Bello, East Carolina University

\begin{abstract}
There have been many studies published concerning predictors of academic performance but few of these studies have examined the impact of prerequisites. As such, we investigated the impact of a prerequisite management course on graduate student performance in an Organizational Behavior $(O B)$ course. In this longitudinal study, we explored predictors of performance in a Master of Business Administration (MBA) Organizational Behavior course. In particular, we found that the grade received in the prerequisite was positively related to subsequent performance in the Organizational Behavior course. In addition, mode of instruction (online versus on campus) was significantly and negatively related to the grade received in Organizational Behavior.
\end{abstract}

Keywords: Academic Performance, Prerequisite Course, Master of Business Administration, Management Course, Online Education

\section{INTRODUCTION}

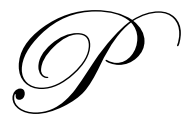

revious research has examined many different factors affecting student performance in business programs. Borde (1998) provides a review of studies that examine a variety of predictors such as gender, race, age, class standing, college entrance test scores, etc. and their impact on academic performance. He concluded that most studies of academic performance in business programs were concerned with accounting, finance, and economics (e.g. Arbaugh, 2000; Bieker, 1996; Deckro \& Woudenberg, 1997; Ekpenyong, 2000; Schaffer \& Calkins, 1980)). There were few studies conducted concerning marketing or management. Since Borde's (1998) study, several articles have appeared regarding student performance in marketing courses (Bacon \& Stewart, 2006; Marcal, Hennessey, Curren, \& Roberts, 2005). The same cannot be said of research concerning student performance in management courses.

Almost ten years later there are still few studies concerned with student academic performance in management courses. It is important to point out that while there are several studies regarding performance in MBA programs, none of them are concerned with specific management courses within the program. In addition, while there have been many studies published concerned with predictors of academic performance, few of these studies have examined the impact of prerequisites. As such, we investigated predictors of graduate student performance in an Organizational Behavior (OB) course.

There were two main purposes for our study. First, we wanted to determine the appropriateness of Comparative Management as a prerequisite for Organizational Behavior. Second, we wanted to examine different predictors of academic performance in the graduate management course. As such, we set out to determine if the grade received in the prerequisite course, mode of delivery, and gender and race predicted performance in the OB course. 


\section{Comparative Management As A Prerequisite For Organizational Behavior}

Comparative Management serves as an introductory course for non-business undergraduates in the MBA program. Furthermore, in order for a business undergraduate applicant to receive a waiver for Comparative Management s/he must have earned a grade of B or better in both Principles/Fundamentals of Management and an international course (such as International Business, International Marketing, International Accounting, or International Finance). Comparative Management is a prerequisite for OB.

Comparative Management is made up of two components. The first component is based on the fundamentals of management while the second component is based on international management. It is the first component that is most closely related to the subsequent course in OB. Material covered in this section of the course focuses on the traditional theories in management. Coverage includes theories related to motivation, leadership, satisfaction, groups/teams, planning, organizing, and control. The Comparative Management course was taught by the same professor for the entire time period under investigation.

The second course in the sequence is Organizational Behavior. This course presents material related to the main principles of $\mathrm{OB}$. The focus of the course is on a practical implementation of research regarding select organizational behavior theories. The course assumes students have some knowledge of many organizational theories. The idea is to present the most up to date research regarding the main principles of organizational behavior. The topics include selection, training and performance appraisals, turnover and satisfaction, motivation, team dynamics, leadership, organizational processes, and work, family, and culture. The same professor taught the Organizational Behavior course during the entire time period under investigation.

\section{Predictors Of Academic Performance}

Prerequisites are standard in college curricula and establish the preconditions for course enrollment. In particular, they serve as a measure of course preparedness. As such, valid prerequisites should increase the likelihood of success in subsequent courses. Performance in lower level accounting courses positively predicted student success in subsequent accounting courses (Eckel \& Johnson, 1983). Previous accounting experience in high school and college positively impacted academic performance in college-level financial accounting course (Dellana, Collins, \& West, 2000). Successful completion of prerequisites was also found to predict student performance in lower level economics courses. For example, Anderson, Benjamin, \& Fuss (1994) found that completion of calculus and economics in high school, predicted performance in subsequent economics courses in college. The completion of a prerequisite business communication course positively impacted performance in a subsequent marketing class (Eskew \& Faley, 1988).

Research supports the fact that undergraduate discipline affects MBA performance (Hancock, 1999). In fact, MBA students with a background in business and management performed better than other MBA students. This increase in academic performance can be attributed to prior knowledge regarding the courses taught in the MBA program. Bieker (1996) found that GPA in a prerequisite common body of knowledge is a better predictor of graduate student academic performance than overall undergraduate GPA. While research has suggested that undergraduate discipline affects MBA performance, results also show that the completion of prerequisites has a positive impact on student performance. Therefore, the performance of students in the Organizational Behavior course should not be impacted by taking the prerequisite or receiving credit for previous comparable coursework. As such, we offer the following hypothesis:

$\mathbf{H}_{1}$ : $\quad$ There will not be a significant difference in the academic performance between students that meet graduate level prerequisite and students that meet the undergraduate prerequisite for the graduate Organizational Behavior course.

While there should not be a significant grade difference between students that meet graduate or undergraduate level requirements there should be a relationship between the grade received in the prerequisite course and the grade received in the OB course. As such we offer the following hypothesis: 
$\mathbf{H}_{2}$ : $\quad$ The grade received in the graduate prerequisite management course will be positively related to the grade received in the graduate Organizational Behavior course.

Research has provided mixed results regarding academic performance in traditional on-campus courses versus distance learning courses. For example, Sonner (1999) found academic performance was higher for students that took distance education classes than students that did not take any distance education classes. Students that took more required courses through distance education performed better than other students. In contrast, Terry (2007) found that students enrolled in online courses scored $4 \%$ lower on the final exam than on-campus students. Research also supports the idea that academic performance is the same for students in traditional on-campus courses and online courses (Anderson, Benjamin, \& Fuss, 1994; Clayton \& Cate, 2004; Fortune, Shifflett, \& Sibley, 2006). In other words, researchers did not find a statistically significant difference in grades between students in the oncampus versus online course. The same can also be said of student perceptions of learning. Students surveyed did not perceive a statistically significant difference between learning online versus on-campus (Doyle \& Wood, 2005). The instructors for each course (OB and $\mathrm{CM}$ ) teach both the online and the on campus sections. As such, we offer the following hypothesis:

H3: The mode of instruction will not be related to the grade received in the OB course.

There have been conflicting reports regarding the impact of gender and race on student academic performance. For example, research has reported there is a correlation between gender and academic performance (Deckro \& Woudernberg, 1997). In particular, female students performed better than male students in academics (Borde, 1998). On the other hand, research studies also report that gender is not related to the academic performance of students (Epkenyong, 2000; Eckel \& Johnson, 1983; Peiperl \& Trevelayn, 1997). Research regarding the impact of race on academic performance has been just as inconsistent. White and Hispanic MBA students achieved higher academic performance than African American MBA students in a study conducted in Kentucky (Cheung \& Kan, 2002). In a separate study, Whites outperformed Hispanics and African Americans in academics (Amy, 2000). However, other studies reveal there is not a significant difference in the academic performance of students across race and ethnicity (Johnson, 2005; Sulaiman \& Mohezar, 2006; Hancock, 1999). As such, we offer the following hypothesis:

$\mathbf{H}_{4}$ : $\quad$ Gender and Race will not be related to the grade received in Organizational Behavior.

\section{METHODOLOGY}

\section{Subjects}

The sample consisted of 471 graduate students who completed the graduate Organizational Behavior course during the Fall 2004 - second summer session 2007 time period. There were a total of twelve semesters, including two sessions each summer. All of the students attended a large southeastern university.

\section{Dependent Variable}

The dependent variable was the grade received by the subjects in Organizational Behavior (an upper level course in the MBA program). Grades were coded with $A=4, B=3, C=2$, and $F=1$.

\section{Independent Variable}

The independent variables included the mode of instruction for both the Organizational Behavior and the prerequisite course, gender, race, whether or not the student took the prerequisite course, and grade in the prerequisite course. Dummy variables were included for mode of instruction, gender, and race. We used a dummy variable to indicate if the student had taken the prerequisite or had not taken the prerequisite prior to completing Organizational Behavior. This variable is referred to as Status. Finally, we included grade earned in the prerequisite course. Grades were coded as indicated above. 


\section{Results}

Table 1 provides the correlation matrix for the first half of the study. The regression results for this study are presented in Table 2. The analysis included all 471 students that took Organizational Behavior during the 3 year time period. The results of the ANOVA revealed that Status was not significantly related to the grade received in Organizational Behavior. Therefore, hypothesis 1 was supported. There was no significant difference in the academic performance between students that met the graduate level prerequisite and students that met the undergraduate prerequisite for the $\mathrm{OB}$ course. The results indicate that the grade received in Comparative Management is positively and significantly related to the grade earned in Organizational Behavior. As such, hypothesis 2 was supported. The grade received in the graduate prerequisite management course was positively related to the grade received in the graduate OB course. In addition, the mode of instruction of Organizational Behavior was significantly and negatively related to the grade received in Organizational Behavior. In other words, students in the online graduate OB course received lower grades than students in the on campus graduate OB course. The mode of instruction of the prerequisite graduate course was not related to the grade received in OB. There was no difference in grades received in OB based on whether the student took the prerequisite as an online or on campus course. As such, Hypothesis 3 was partially supported. Finally, gender was negatively and statistically significant as predictor of academic performance in the Organizational Behavior course. In essence, it appears that male students performed better in our study in the OB course. Race however, was not significantly related to the grade earned in OB. Hypothesis 4 was not supported for gender but was supported for race. The R-square for our model explained 0.091 of the variance in OB grades.

Table 1

Correlation Matrix

\begin{tabular}{|c|c|c|c|c|c|c|c|c|}
\hline & $\begin{array}{c}\text { CM } \\
\text { Grade }\end{array}$ & $\begin{array}{c}\text { Mode of } \\
\text { Instruction CM }\end{array}$ & $\begin{array}{c}\text { OB } \\
\text { Grade }\end{array}$ & $\begin{array}{c}\text { OB } \\
\text { Term }\end{array}$ & $\begin{array}{c}\text { Mode of } \\
\text { Instruction OB }\end{array}$ & $\begin{array}{c}\text { Gende } \\
\text { r }\end{array}$ & Race & Status \\
\hline CM Grade & 1.00 & & & & & & & \\
\hline $\begin{array}{c}\text { Mode of } \\
\text { Instruction CM }\end{array}$ & $.891^{* *}$ & 1.00 & & & & & & \\
\hline OB Grade & $.134^{* *}$ & $.105^{*}$ & 1.00 & & & & & \\
\hline OB Term & $-.296^{* *}$ & $-.272^{* *}$ & $.122^{* *}$ & 1.00 & & & & \\
\hline $\begin{array}{c}\text { Mode of } \\
\text { Instruction OB }\end{array}$ & .076 & $.148^{* *}$ & $-.177^{* *}$ & $-.247^{* *}$ & 1.00 & & & \\
\hline Gender & .048 & .030 & $-.132^{* *}$ & .007 & $-.106^{*}$ & 1.00 & & \\
\hline Race & -.019 & .036 & -.038 & -.067 & $.138^{* *}$ & -.034 & 1.00 & \\
\hline Status & $.934 * *$ & $.946^{* *}$ & $.099^{*}$ & $-.295^{* *}$ & $.095^{*}$ & .040 & .030 & 1.00 \\
\hline
\end{tabular}

$* *<.01 \quad \mathrm{~N}=471, *<.05$

Table 2

\begin{tabular}{|c|c|c|c|c|c|c|}
\hline & \multicolumn{2}{|c|}{ Sum of Squares } & df & Mean Squares & $\mathbf{F}$ & Sig. \\
\hline $\begin{array}{l}\text { Regression } \\
\text { Residual } \\
\text { Total } \\
\end{array}$ & \multicolumn{2}{|c|}{$\begin{array}{c}42.648 \\
428.352 \\
471.000\end{array}$} & $\begin{array}{c}9 \\
461 \\
470 \\
\end{array}$ & $\begin{array}{c}4.739 \\
.929\end{array}$ & 5.100 & .000 \\
\hline & \multicolumn{2}{|c|}{ Standardized Coefficients } & \multirow[t]{2}{*}{ df } & \multirow[t]{2}{*}{$\mathbf{F}$} & \multirow[t]{2}{*}{ Sig. } & \\
\hline & Beta & Std. Error & & & & \\
\hline Mode of Instruction CM & .174 & .142 & 2 & 1.493 & .226 & \\
\hline Mode of Instruction OB & -.212 & .046 & 1 & 21.284 & .000 & \\
\hline Gender & -.164 & .045 & 1 & 13.475 & .000 & \\
\hline Race & -.026 & .045 & 1 & .334 & .564 & \\
\hline Status & -.280 & .160 & 1 & 3.055 & .081 & \\
\hline Grade in CM & .268 & .099 & 3 & 7.332 & .000 & \\
\hline
\end{tabular}

R square - .091

Adjusted R square - .073 


\section{DISCUSSION AND IMPLICATIONS}

There have been few studies concerned with academic performance in management courses. While there are several studies that examined MBA student performance none of them included specific management courses. This study offers a unique contribution in that it is the only study that has analyzed predictors of performance for MB A students in a graduate management course. In particular, this study offers guidance related to the impact of mode of instruction in a graduate management course. More importantly however, the study provides support for retaining the current prerequisites for the $\mathrm{OB}$ course.

Results indicate that there was no significant difference in OB grade between students that met the undergraduate prerequisite courses and students that met the graduate level prerequisite course. In addition, the grade received in the prerequisite Comparative Management course was positively and significantly related to the grade received in the OB course. Interestingly, the grades of students enrolled in the online sections of the OB course were lower than students enrolled in the on campus sections of the OB course. This is interesting because the same professor taught both the online and the on campus sections. In addition, the material was the same, including the same textbooks, the same written assignments, and the same type of exams. There were a few differences, the most obvious being the interaction with the professor. The online students were only able to interact with the professor via email and Blackboard. Further research is needed to identify the cause of the difference in grades. Finally, gender was negatively and significantly related to the grade received in OB to the extent that it appears that male students performed better than the female counterparts. This is interesting because previous research has presented conflicting results. Race was not related to the grade received in the OB course.

The results are encouraging for the MBA program that was the focus of this study. In setting up prerequisites for upper level courses in academia, more often than not, it is assumed that 'face validity' is sufficient. In other words, there are very few studies, especially in MBA programs that have examined and tested for the content validity of course prerequisites. While there are potentially a myriad of variables to explain successful completion of the MBA degree, certain variables like prerequisites need to be tested to validate the total coursework required. The results of the current study indicate that the course prerequisite for Organizational Behavior at the institution under investigation is appropriate. This is an important finding for the administrator of an MBA program in developing the sequencing of courses for the successful completion of an MBA. The fact that there was no significant difference in OB grades between students that met the undergraduate requirements and students that met the graduate requirements is encouraging for the current curriculum requirements.

This is the first step in validating the coursework required for the MBA program at the institution in this study. Administrators and faculty alike were beginning discussions surrounding the current MBA curriculum. This study was an outcome of these first conversations. Based on the results of this study, the MBA administrator has already requested that similar studies be done for other courses. This is in part because certain course prerequisites do not appear to have any 'face validity'. Nevertheless, there must be adequate and sufficient evidence to change the current curriculum.

There were several limitations with this study. First, while the grades received in the prerequisite and the grades received in OB were significantly and positively related, we cannot imply causality. Second, the predictors of performance included in this study are by no means exhaustive. Future research should include other possible predictors of MBA academic performance such as job experience, teaching style, and age. In addition, research should also consider other possible prerequisite for MBA courses. Course sequence is another area needing further examination.

\section{REFERENCES}

1. Amy, A. (2000). Work experience as a predictor of MBA performance. College Student Journal, 30, 361 366.

2. Anderson, G., Benjamin, D.\& Fuss, M. A. (1994). Research in economic education: The determinants of success in university introductory economics courses. Journal of Economic Education, 25, (2), 99-120. 
3. Arbaugh, J.B. (2000). Virtual classroom versus physical classroom: an exploratory study of class discussion patterns and student learning in an asynchronous Internet-based MBA course. Journal of Management Education, 24, (2), 213-233.

4. Bacon, D.R., \& Stewart, K.A. (2006). How fast do students forget what they learn in Consumer Behavior? A longitudinal study. Journal of Marketing Education, 28 (3), 181-192.

5. Bieker, R. F. (1996). Factors affecting academic achievement in graduate management education. Journal of Education for Business, 72, (1), 42-46.

6. Borde, S. F. (1998).Predictors of student academic performance in the introductory marketing course. Journal of Education for Business, 73, (5), 302-306.

7. Cheung, L. L.W. \& Kan, A.C.N. (2002). Evaluation of factors related to student performance in a distancelearning business communication course. Journal of Education for Business, 77, (5), 257-263.

8. Clayton, G. E. \&Cate, T.(2004). Predicting MBA no-shows and graduation success with discriminative analysis. International Advances in Economic Research, 10, (3), 235-243.

9. Deckro, R. \&Woudenberg, H. (1997).MBA admission criteria and academic success. Decision Science, 8, $765-769$.

10. Dellana, S. A., Collins, W. H. \& West, D. (2000). On-line education in a management science course: Effectiveness and performance factors. Journal of Education for Business, 76, (1), 43-47.

11. Doyle, J. M. \& Wood, W. C. (2005). Principles course assessment, accreditation and the depreciation of economic knowledge. Journal of Education for Business, 80, (3), 165-171.

12. Eckel, N., \& Johnson, W.A. (1983). A model for screening and classifying potential accounting majors. Journal of Accounting Education, Fall, 57 - 65.

13. Ekpenyong, B. (2000). Empirical analysis of the relationship between students' attributes and performance: A case study of the University of Ibadan (Nigeria) MBA programme. Journal of Financial Management \& Analysis, 13, (2), $54-63$.

14. Eskew, R. K. \&Faley, R. H. (1988).Some determinants of student performance in the first college-level financial accounting course. The Accounting Review, 63, (1), 137-147.

15. Fortune, M. F., Shifflett, B.\& Sibley, R. E. (2006).A comparison of online (high tech) and traditional (high touch) learning in business communication courses in Silicon Valley. Journal of Education for Business, $81,(4), 210-214$.

16. Hancock, T.(1999). The gender difference: validity of standardized admission tests in predicting MBA performance. Journal of Education for Business, 75, (2), 91-93.

17. Johnson, M. (2005).Academic performance of transfer versus native students. College Student Journal, 39 , $570-580$.

18. Marcal, L. E., Hennessey, J. E., Curren, M. T. \& Roberts, W. W. (2005). Do business communication courses improve student performance in introductory marketing? Journal of Education for Business, 80 , (5), 289-294.

19. Peiperl, M, \&Trevelayn, R. (1997). Predictors of performance at business school and beyond: Demographic factors and the contrast between individual and group outcomes. Journal of Management Development, 16, (5), $354-367$.

20. Schaffer, B. F. \& Calkins, D. O. (1980). An appraisal of prerequisistes to business finance. Journal of Financial Education, Fall, 51 - 55.

21. Sonner, B. (1999). Success in the capstone business course: Assessing the effectiveness of distance learning. Journal of Education for Business, 74, (4), 243-247.

22. Sulaiman, A.\& Mohezar, S. (2006). Student success factors: identifying key predictors. Journal of Education for Business, 81, (6), 328-333.

23. Terry, N. (2007). Assessing instruction modes for Master of Business Administration courses. Journal of Education for Business, 82,(4), 220-226. 